Article

\title{
A Three-Step Process for the Bioconversion of Whey Permeate into a Glucose-Free D-Tagatose Syrup
}

\author{
Fadia V. Cervantes ${ }^{1}{ }^{(}$, Sawssan Neifar ${ }^{2}$, Zoran Merdzo ${ }^{3}{ }^{\circledR}$, Javier Viña-Gonzalez ${ }^{1}$, \\ Lucia Fernandez-Arrojo ${ }^{1}$, Antonio O. Ballesteros ${ }^{1}$, Maria Fernandez-Lobato ${ }^{3}{ }^{\circledR}$, Samir Bejar ${ }^{2}$ \\ and Francisco J. Plou 1,*(D) \\ 1 Instituto de Catálisis y Petroleoquímica, CSIC, 28049 Madrid, Spain; fadiacervantes@icp.csic.es (F.V.C.); \\ javier.v@csic.es (J.V.-G.); lucia@icp.csic.es (L.F.-A.); a.ballesteros@icp.csic.es (A.O.B.) \\ 2 Laboratory of Microbial Biotechnology and Engineering Enzymes (LMBEE), Centre of Biotechnology of \\ Sfax (CBS), University of Sfax, Sfax 3018, Tunisia; neifarsawssan@yahoo.fr (S.N.); \\ samir.bejar@cbs.rnrt.tn (S.B.) \\ 3 Centro de Biología Molecular Severo Ochoa, UAM-CSIC, 28049 Madrid, Spain; zoran@cbm.csic.es (Z.M.); \\ mfernandez@cbm.csic.es (M.F.-L.) \\ * Correspondence: fplou@icp.csic.es; Tel.: +34-91-5854869
}

Received: 15 May 2020; Accepted: 8 June 2020; Published: 9 June 2020

\begin{abstract}
We have developed a sustainable three-stage process for the revaluation of cheese whey permeate into D-tagatose, a rare sugar with functional properties used as sweetener. The experimental conditions ( $\mathrm{pH}$, temperature, cofactors, etc.) for each step were independently optimized. In the first step, concentrated whey containing $180-200 \mathrm{~g} / \mathrm{L}$ of lactose was fully hydrolyzed by $\beta$-galactosidase from Bifidobacterium bifidum (Saphera ${ }^{\circledR}$ ) in $3 \mathrm{~h}$ at $45^{\circ} \mathrm{C}$. Secondly, glucose was selectively removed by treatment with Pichia pastoris cells for $3 \mathrm{~h}$ at $30^{\circ} \mathrm{C}$. The best results were obtained with $350 \mathrm{mg}$ of cells (previously grown for $16 \mathrm{~h}$ ) per $\mathrm{mL}$ of solution. Finally, L-arabinose isomerase US100 from Bacillus stearothermophilus was employed to isomerize D-galactose into D-tagatose at $\mathrm{pH} 7.5$ and $65^{\circ} \mathrm{C}$, in presence of $0.5 \mathrm{mM} \mathrm{MnSO}_{4}$. After $7 \mathrm{~h}$, the concentration of D-tagatose was approximately $30 \mathrm{~g} / \mathrm{L}$ (33.3\% yield, referred to the initial D-galactose present in whey). The proposed integrated process takes place under mild conditions (neutral $\mathrm{pH}$, moderate temperatures) in a short time (13 h), yielding a glucose-free syrup containing D-tagatose and galactose in a ratio 1:2 $(w / w)$.
\end{abstract}

Keywords: biocatalysis; glycosidases; isomerases; Pichia pastoris; sweeteners; rare sugars; cheese whey; sustainable chemistry

\section{Introduction}

D-Tagatose is one of the most promising low-calorie functional sweeteners [1]. It is a ketohexose, namely a C4 epimer of D-fructose. It is a rare sugar only found at small quantities in the gum exudates of the tropical tree Sterculia setigera and in several dairy products, e.g., in Ultra-High-Temperature (UHT) sterilized cow's milk [2]. It is heat tolerant, very stable at $\mathrm{pH}$ values between 2.0 to 7.0 , and highly soluble in water ( $58 \% w / w$ at room temperature). It possesses a sucrose-like taste with $92 \%$ of its sweetness but contributing only $1.5 \mathrm{kcal} / \mathrm{g}$ ( $38 \%$ compared to sucrose) [3], with no cooling effect or aftertaste [4]. D-Tagatose was approved as a novel food in the European Union [3] and has obtained GRAS status by FDA in USA [5]. It is also approved in many other countries and is being widely used in foods, beverages, and dietary supplements [6,7].

Only $20 \%$ of the ingested D-tagatose is absorbed in the small intestine [8]. Since the remaining $80 \%$ seems to favourably modulate the composition of the gut microbiota [9], this sugar has been proposed as a potential prebiotic. In addition, D-tagatose is able to modulate lipid metabolism, minimize tooth 
decay, promote blood health, and reduce the symptoms associated with type 2 diabetes, hyperglycemia, anemia, and haemophilia [10-12].

Several chemical $[13,14]$ and chemoenzymatic $[15,16]$ methods have been described for D-tagatose synthesis. In this context, the chemical manufacture of D-tagatose involves the use of metal hydroxides and calcium chloride, the neutralization with mineral acids and the implementation of complex purification steps due to by-product generation [6]. Therefore, enzymatic methods are the most appropriate for D-tagatose production in terms of selectivity, efficiency and environmental impact [17]. Several enzymes have been investigated for D-tagatose synthesis, e.g. phosphoglucose isomerase [18], galactitol 2-dehydrogenase [19] and L-arabinose isomerase (L-AI) [20]. The main reaction catalyzed by L-AI is the bioconversion of L-arabinose into L-ribulose, however, it also promotes efficiently the isomerization of D-galactose to D-tagatose [21]. In fact, most of the publications on the enzymatic synthesis of D-tagatose use L-AI as biocatalyst [22-24].

D-Tagatose production typically begins with D-galactose [25-28], which is quite expensive in its pure form. The valorization of galactose-rich byproducts such as agar [29] or whey [30] is much more attractive from the economic and environmental points of view. Moreover, cheese whey generates significant environmental and health issues due to its large volume production and high organic content [31]. With this aim in mind, several groups have reported the production of D-tagatose from cheese whey in liquid or powdered form [30,32-36], yielding a mixture of D-tagatose, D-galactose and D-glucose. Since the physicochemical properties of the three monosaccharides are quite similar, the isolation of pure D-tagatose is a difficult task [32].

In order to increase the efficiency of the process, several groups have co-expressed $\beta$-galactosidase and L-AI in Pichia pastoris [37], Corynebacterium glutamicum [33] or Escherichia coli [30,32,38] for the simultaneous lactose hydrolysis and D-galactose isomerization. The main drawback of this approach is that the optimum $\mathrm{pH}$ and temperature of $\mathrm{L}-\mathrm{AI}$ and $\beta$-galactosidase are substantially different, thus limiting the efficiency of the whole process.

The presence of D-glucose in D-tagatose syrups is clearly undesirable, especially because one of the main properties of D-tagatose is its antidiabetic effect [6]. In order to eliminate the glucose released during lactose hydrolysis, Wanarska et al. took advantage of the presence of glucose to cultivate Pichia pastoris (which co-expressed L-AI and $\beta$-galactosidase) [37]. Another approach addressed by Zhan et al. [39] and Zheng et al. [32] was the implementation of a second step of D-glucose (and eventually D-galactose) fermentation by Saccharomyces cerevisiae which may render both D-tagatose and bioethanol.

In this work, we report a three-step process for the bioconversion of concentrated whey permeate into D-tagatose using free enzymes and whole cells. In the first stage, $\beta$-galactosidase hydrolyzed lactose. This was followed by treatment with Pichia pastoris cells to remove the released D-glucose. Finally, L-AI isomerized D-galactose into D-tagatose. The three stages were independently optimized to obtain the highest efficiency.

\section{Results and Discussion}

\subsection{Chemical Composition of Whey Permeate}

It is well reported the effect of metal ions on the activity and stability of many enzymes, including those involved in the transformation of carbohydrates, and in particular in the two enzymes involved in the present work: $\beta$-galactosidase [40] and L-arabinose isomerase [41]. In particular, several members of these two families are activated by divalent cations such as $\mathrm{Co}^{2+}, \mathrm{Mn}^{2+}$ and $\mathrm{Mg}^{2+}[21,42]$. For that reason, we measured by semiquantitative ICP-MS the composition of the concentrated whey permeate employed in this work. Table 1 summarizes the concentration of metal ions present at higher amounts than $0.1 \mathrm{ppm}$. As shown, the concentration of $\mathrm{Mg}^{2+}$ was significant $(98 \mathrm{mg} / \mathrm{L})$ but the presence of $\mathrm{Co}^{2+}$ and $\mathrm{Mn}^{2+}$ was negligible. 
Table 1. Metal ions present in whey permeate at concentrations higher than $0.1 \mathrm{ppm}$, determined by semiquantitative ICP-MS.

\begin{tabular}{cc}
\hline Analyte & Concentration (ppm) \\
\hline $\mathrm{Na}$ & 390 \\
$\mathrm{Mg}$ & 98 \\
$\mathrm{~K}$ & 1492 \\
$\mathrm{Ca}$ & 829 \\
$\mathrm{Ti}$ & 0.35 \\
$\mathrm{Fe}$ & 0.18 \\
$\mathrm{Zn}$ & 1.1 \\
$\mathrm{Rb}$ & 1.6 \\
$\mathrm{Sr}$ & 0.45 \\
$\mathrm{Mo}$ & 0.1 \\
\hline
\end{tabular}

\subsection{Hydrolysis of Whey Permeate by $\beta$-Galactosidase from Bifidobacterium bifidus}

The concentration of lactose in the cheese whey permeates employed in this work varied between $180-200 \mathrm{~g} / \mathrm{L}$ depending on the batch, as determined by HPAEC-PAD. The $\mathrm{pH}$ of whey was adjusted to 6.8. We selected Bifidobacterium bifidum $\beta$-galactosidase (Saphera ${ }^{\circledR}$, Novozymes, Bagsværd, Denmark) for the hydrolysis of lactose in whey because we recently observed that at lactose concentrations lower than $200 \mathrm{~g} / \mathrm{L}$ the main reaction catalyzed by this enzyme is the hydrolysis with negligible transgalactosylation [43]. In order to standardize the dose of enzyme, we measured the activity of Saphera with $o$-nitrophenyl- $\beta$-D-galactopyranoside (ONPG). The activity was $1506 \pm 0.1 \mathrm{U} / \mathrm{mL}$ at $40{ }^{\circ} \mathrm{C}$ and $\mathrm{pH}$ 6.8, which are the typical preferred conditions for several $\beta$-galactosidases from Bifidobacteria $[44,45]$.

First, we analyzed the effect of temperature on lactose hydrolysis in whey permeate. We assayed three different temperatures $\left(30,40\right.$ and $45^{\circ} \mathrm{C}$ ) using $2.5 \mu \mathrm{L}$ (3.75 ONPG units) per $\mathrm{mL}$ of whey. HPAEC-PAD showed that the fastest reaction was the one performed at $45^{\circ} \mathrm{C}$ (Table 2). Under these conditions, all the lactose is hydrolyzed in $3 \mathrm{~h}$. We further increased the enzyme concentration up to 7.50 ONPG units per $\mathrm{mL}$ but the improvement in the hydrolysis process was not substantial. In order to minimize the cost for the process, we selected the lowest concentration of this enzyme.

Table 2. Effect of temperature on the progress of lactose hydrolysis in whey permeate by Saphera, using $2.5 \mu \mathrm{L}$ of enzyme (3.75 ONPG units) per mL of whey permeate.

\begin{tabular}{|c|c|c|c|c|c|c|}
\hline \multirow{2}{*}{$\begin{array}{c}\text { Temperature } \\
\left({ }^{\circ} \mathrm{C}\right)\end{array}$} & \multicolumn{6}{|c|}{ Residual lactose (\%) ${ }^{a}$} \\
\hline & $30 \mathrm{~min}$ & $60 \mathrm{~min}$ & $90 \mathrm{~min}$ & $120 \mathrm{~min}$ & $150 \mathrm{~min}$ & $180 \mathrm{~min}$ \\
\hline 30 & 89.3 & 81.5 & 76.6 & 65.5 & 57.1 & 24.7 \\
\hline 40 & 73.4 & 45.6 & 39.7 & 36.9 & 21.3 & 18.7 \\
\hline 45 & 76.3 & 31.7 & 29.8 & 26.1 & 10.7 & 0 \\
\hline
\end{tabular}

\subsection{Study of the Growth Time and Concentration of Pichia pastoris for Elimination of D-Glucose}

Pichia pastoris is capable of using D-glucose, glycerol and methanol as carbon sources but not D-galactose [46]. In this context, Avila-Fernandez et al. successfully employed P. pastoris cells to selectively eliminate glucose and fructose in a syrup of fructooligosaccharides obtained by agave fructan hydrolysis [47]. Based on such background, the elimination of D-glucose using P. pastoris cells was postulated for the second step of the reaction.

We first developed a simple and fast test to evaluate the effect of $P$. pastoris growing time on the further consumption of glucose. Thus, samples from a P. pastoris culture were taken every two hours (after an initial lag phase of $6 \mathrm{~h}$ ), and the absorbance at $600 \mathrm{~nm}$ (as turbidity measurement) of all samples was adjusted to the absorbance at $6 \mathrm{~h}$, to have the same concentration of cells but with 
different growing times. The P. pastoris cells were then mixed with a solution containing $1 \mathrm{~g} / \mathrm{L}$ of both D-glucose and D-galactose, and the mixture was incubated for $10 \mathrm{~min}$ at $30^{\circ} \mathrm{C}$. The cells were separated by centrifugation and the concentration of both sugars was analyzed by HPAEC-PAD (Figure 1). Our results showed that the most voracious cells were those corresponding to $12-16 \mathrm{~h}$ growing time. It is well reported that these times correspond the exponential phase of growth of P. pastoris [48].

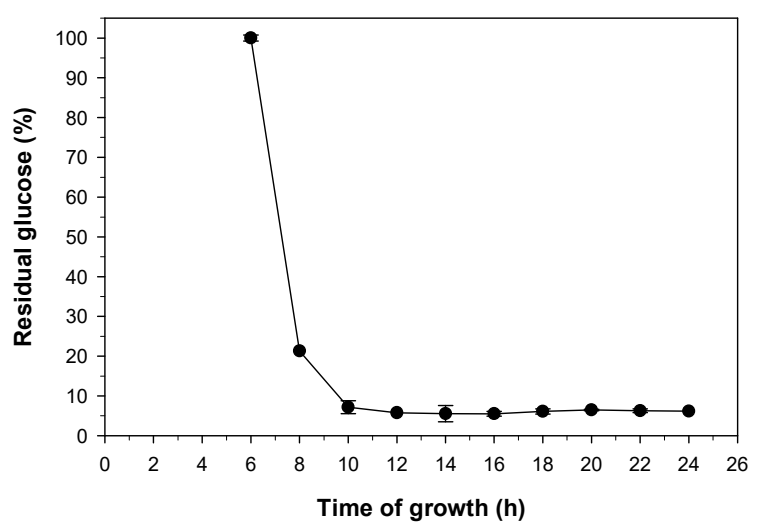

Figure 1. Effect of the growth time of Pichia pastoris on the elimination of D-glucose. Experimental conditions: $1 \mathrm{~g} / \mathrm{L} \mathrm{D}$-glucose, $1 \mathrm{~g} / \mathrm{L}$ D-galactose, $10 \mathrm{~min}, 30^{\circ} \mathrm{C}$.

The next step was to determine the amount of cells (grown for $16 \mathrm{~h}$ ) required to consume the glucose (90-100 g/L) released after lactose hydrolysis in whey permeate. Different amounts of Pichia pastoris cells (100-600 mg of wet weight) were added to $1 \mathrm{~mL}$ of a solution containing $100 \mathrm{~g} / \mathrm{L}$ of D-glucose and $100 \mathrm{~g} / \mathrm{L}$ D-galactose. The residual glucose was analyzed at 1, 2 and $3 \mathrm{~h}$ by HPAEC-PAD (Figure 2). As illustrated, the glucose disappeared in one hour using $600 \mathrm{mg}$ of $P$. pastoris cells per $\mathrm{mL}$. However, adding $350 \mathrm{mg}$ of cells per $\mathrm{mL}$, the total disappearance of glucose took place in two hours, and the mass transfer limitations were less significant than with $600 \mathrm{mg}$ cells per mL. On this basis, we selected $350 \mathrm{mg}$ of cells per $\mathrm{mL}$ ( $3 \mathrm{~h}$ incubation) to assure the elimination of glucose in the integrated 3-step process for D-tagatose synthesis.

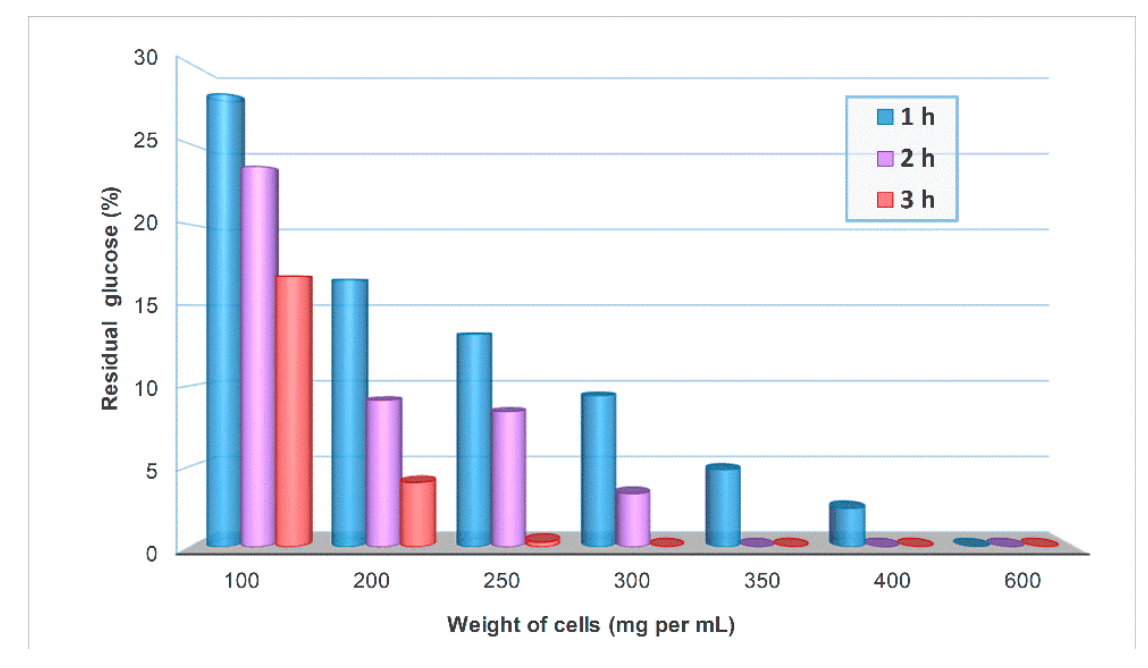

Figure 2. Effect of the amount of cells (wet weight) of Pichia pastoris on the elimination at $30{ }^{\circ} \mathrm{C}$ of D-glucose in a solution containing $100 \mathrm{~g} / \mathrm{L}$ of both D-glucose and D-galactose.

\subsection{Effect of $\mathrm{pH}$ and Temperature on the Stability of L-Arabinose Isomerase}

The L-arabinose isomerase (L-AI US100) from Bacillus stearothermophilus is a multimeric enzyme formed by four $56 \mathrm{kDa}$ monomers [49]. Compared with other L-arabinose isomerases, L-AI US100 is 
relatively active at neutral and slightly acidic $\mathrm{pH}$, and at moderate temperatures [50]. These properties are very valuable because at the typical conditions of alkaline $\mathrm{pH}$ and high temperature the formation of undesired byproducts in bioconversions of sugars is quite common [51]. For these reasons, L-AI US100 was selected for the transformation of whey permeate into D-tagatose.

In order to establish the optimal conditions for the biotransformation, the stability of L-AI US100 towards $\mathrm{pH}$ was evaluated by pre-incubation (at room temperature) of the enzyme for $1 \mathrm{~h}$ at $\mathrm{pH}$ values between 3.0 and 10.0 employing $0.1 \mathrm{M}$ Britton \& Robinson buffer. After that, the L-arabinose isomerase activity was measured following the standard activity assay $\left(\right.$ at $65^{\circ} \mathrm{C}$ and $\mathrm{pH} 7.5$, see Experimental Section). The results shown in Figure 3A represent the relative activity of pre-treated L-AI compared with the non-incubated enzyme. As illustrated, the enzyme is very unstable at $\mathrm{pH}$ values below 6.0 and is notably stable at neutral and moderately alkaline $\mathrm{pH}$ values.
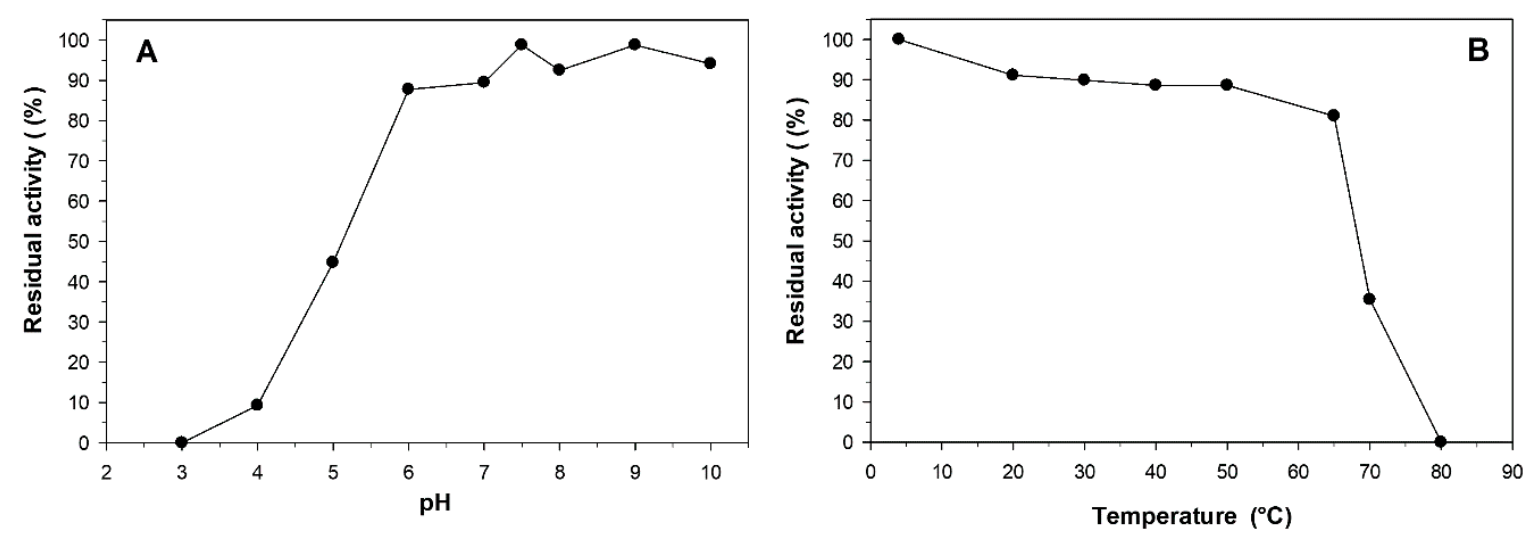

Figure 3. Stability of L-arabinose isomerase US100 from Bacillus stearothermophilus towards: (A) pH; (B) temperature. The pre-incubation time in both cases was $1 \mathrm{~h}$.

The thermal stability of the enzyme was determined by pre-incubating the L-AI US100 for $1 \mathrm{~h}$ at temperatures between 4 and $80^{\circ} \mathrm{C}$ in $100 \mathrm{mM}$ MOPS buffer (pH 7.5). Following this incubation, the L-AI activity was measured by the standard activity assay (at $65^{\circ} \mathrm{C}$ and $\left.\mathrm{pH} 7.5\right)$. As shown in Figure 3B, the enzyme is very stable at temperatures up to $65^{\circ} \mathrm{C}$, and was fast inactivated at temperatures higher than $70^{\circ} \mathrm{C}$.

\subsection{Effect of Cofactors, $p H$ and Temperature on the Activity of L-Arabinose Isomerase}

The effect of metal cofactors on the activity of L-arabinose isomerase (L-AI US100) from B. stearothermophilus at $65^{\circ} \mathrm{C}$ and neutral $\mathrm{pH}$ was assessed. Four different reactions were performed in absence or presence of $0.5 \mathrm{mM} \mathrm{MnSO}_{4}$ and/or $0.1 \mathrm{mM} \mathrm{CoCl}_{2}$. The reactions were carried out with $20 \mathrm{~g} / \mathrm{L}$ galactose in $100 \mathrm{mM}$ MOPS buffer (pH 7.5) at $65^{\circ} \mathrm{C}$ for $4 \mathrm{~h}$. Results are displayed in Figure 4.

As shown, $\mathrm{CoCl}_{2}$ had a negligible effect on the yield of D-tagatose under these conditions. However, the production of D-tagatose in the presence of $0.5 \mathrm{mM} \mathrm{MnSO}_{4}$ was approximately $40 \%$ higher compared with the control.

These results correlate well with previous findings on the effect of metallic ions on the L-AI US100 activity and thermostability. The effect of divalent cations on L-AI US100 must be particularly considered at temperatures higher or equal to $65^{\circ} \mathrm{C}$ [49]. In fact, at temperatures above $65^{\circ} \mathrm{C}$ both $\mathrm{Mn}^{2+}$ and $\mathrm{Co}^{2+}$ exert a significant influence on the thermostability of L-AI US100. Since a temperature of $65^{\circ} \mathrm{C}$ was selected for the isomerization reaction, and considering that the conversion from D-galactose to D-tagatose was higher in presence of $\mathrm{MnSO}_{4}$ in the reaction medium, we decided to maintain $\mathrm{MnSO}_{4}$ but not $\mathrm{CoCl}_{2}$ in the integrated process from whey to D-tagatose. 


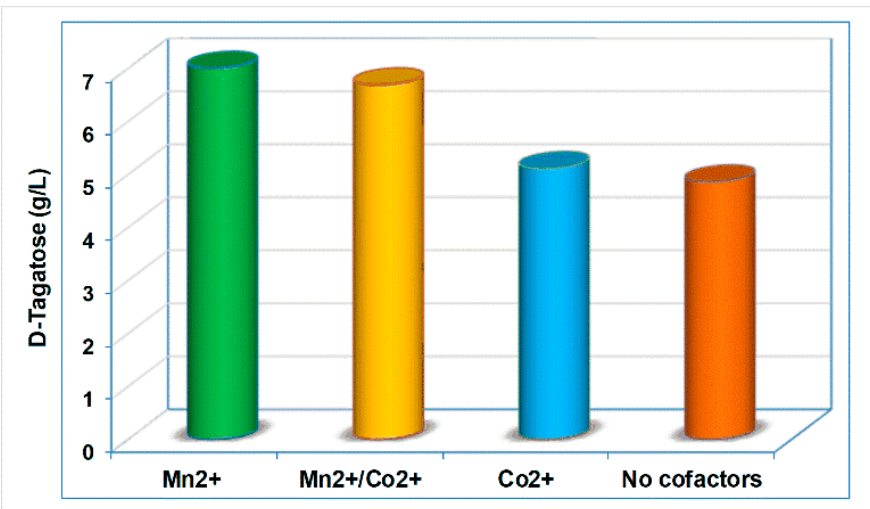

Figure 4. Effect of metal ions on the activity of L-arabinose isomerase US100 from B. stearothermophilus, in absence or presence of $0.5 \mathrm{mM} \mathrm{MnSO}_{4}$ and/or $0.1 \mathrm{mM} \mathrm{CoCl}_{2}$. Experimental conditions: $20 \mathrm{~g} / \mathrm{L}$ D-galactose, $100 \mathrm{mM}$ MOPS (pH 7.5), $0.65 \mathrm{U} / \mathrm{mL} \mathrm{L-AI,} 65^{\circ} \mathrm{C}$. The concentration of D-tagatose was measured after $4 \mathrm{~h}$ by HPAEC-PAD.

Furthermore, we analysed the effect of $\mathrm{pH}$ and temperature on the production of D-tagatose. We selected the range of $\mathrm{pH}(7.0-9.5)$ and temperature $\left(40-65^{\circ} \mathrm{C}\right)$ at which the L-arabinose isomerase from B. stearothermophilus was stable (see Figure 3). The reactions were carried out with $20 \mathrm{~g} / \mathrm{L}$ galactose in $100 \mathrm{mM}$ MOPS buffer for $4 \mathrm{~h}$, in presence of $0.5 \mathrm{mM} \mathrm{MnSO}_{4}$. Results are shown in Figure 5. It remains clear that temperature substantially affects the reaction course. The highest production of D-tagatose in $4 \mathrm{~h}(7-8 \mathrm{~g} / \mathrm{L}, 35-40 \%$ yield $)$ was achieved at $65^{\circ} \mathrm{C}$. The reaction was $6-7$ fold faster than at $40{ }^{\circ} \mathrm{C}$. Regarding the $\mathrm{pH}$, its effect was very much lower than that of temperature (Figure 5).

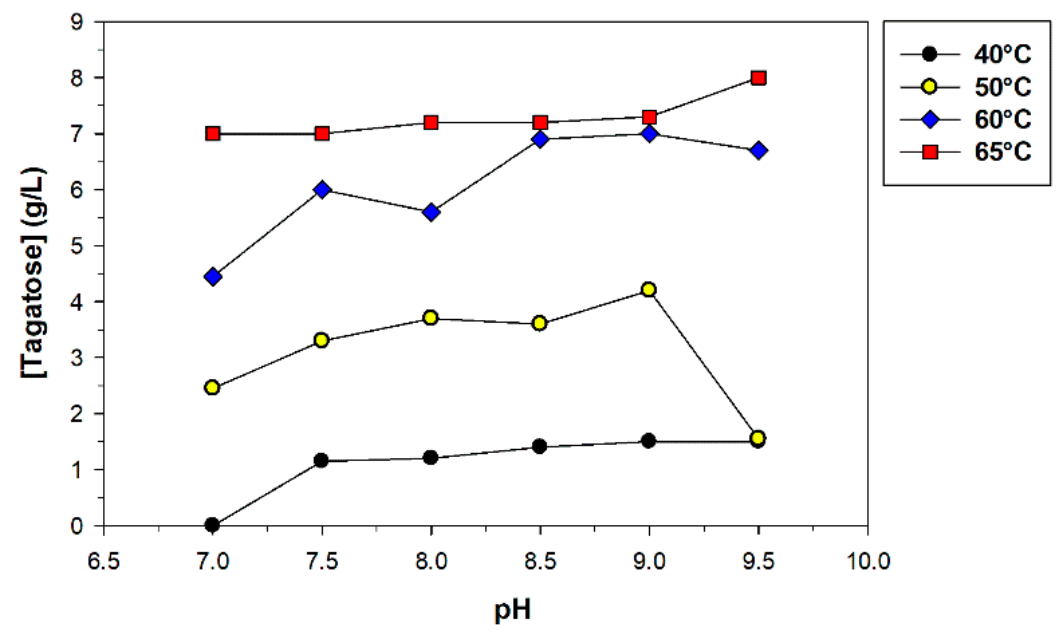

Figure 5. Effect of temperature and $\mathrm{pH}$ on the production of D-tagatose by L-arabinose isomerase US100 from B. stearothermophilus. Experimental conditions: $20 \mathrm{~g} / \mathrm{L}$ D-galactose in buffer $100 \mathrm{mM}$ MOPS containing $0.5 \mathrm{mM} \mathrm{MnSO}_{4}, 0.65 \mathrm{U} / \mathrm{mL}$ L-AI. The concentration of D-tagatose was measured after $4 \mathrm{~h}$ by HPAEC-PAD.

Considering the results on the effect of $\mathrm{pH}$, temperature and metal cofactors on the stability and activity of L-AI US100, we selected $\mathrm{pH} 7.5,65^{\circ} \mathrm{C}$ and $0.5 \mathrm{mM} \mathrm{MnSO}_{4}$ as the optimal experimental conditions for the integrated process. These results represent a compromise between activity and stability of the enzyme and correlate well with previous studies reported with this enzyme by using fast spectrophotometric assays $[49,50,52]$ rather than chromatographic analysis by HPAEC-PAD performed in this work. 


\subsection{Sequential Biotransformation of Whey Permeate into D-Tagatose}

We propose a three-step process for D-tagatose synthesis from whey permeate based on the experimental conditions that were previously optimized. In the first stage, the lactose (180-200 g/L) contained in whey is hydrolyzed by $\beta$-galactosidase from Bifidobacterium bifidum (7.5 U/mL). Total hydrolysis is achieved in $3 \mathrm{~h}$ at $45^{\circ} \mathrm{C}$. Figure 6 shows a HPAEC-PAD chromatogram illustrating the complete disappearance of lactose in the reaction medium.

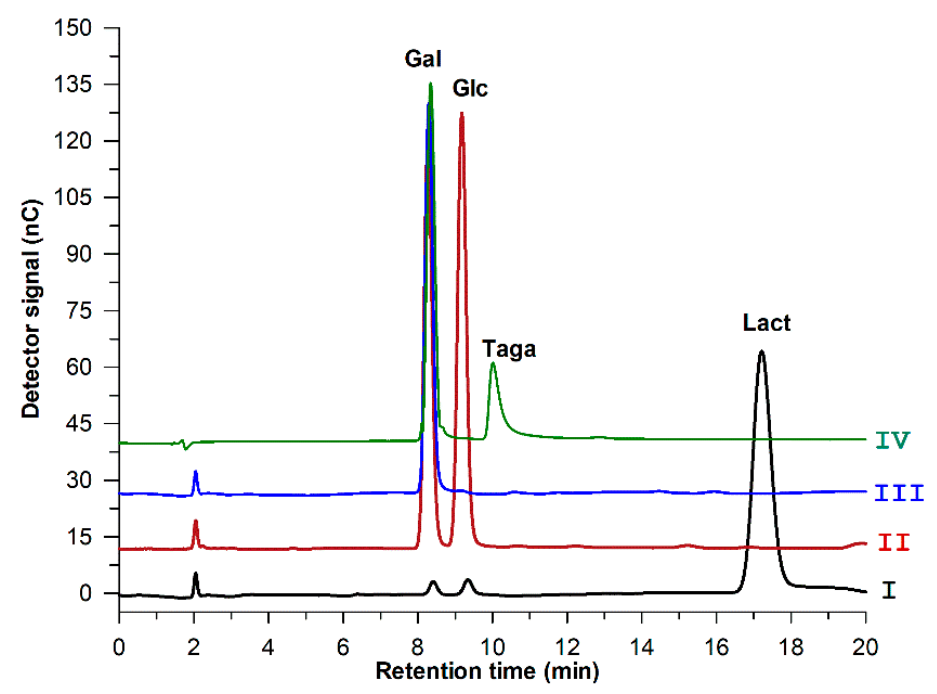

Figure 6. HPAEC-PAD chromatograms showing the bioconversion of whey permeate into D-tagatose syrup. (I) Original whey permeate; (II) After treatment with $\beta$-galactosidase from B. bifidum; (III) After removal of glucose with P. pastoris cells; (IV) After isomerization with of L-arabinose isomerase US100. Gal: D-Galactose; Glc: D-glucose; Taga: D-tagatose; Lact: D-Lactose.

In the second step, the hydrolyzate is treated with Pichia pastoris cells (350 mg of cells per $\mathrm{mL}$, obtained as described elsewhere) during $3 \mathrm{~h}$ at $30^{\circ} \mathrm{C}$. As shown in Figure 6, all the glucose is metabolized by the yeast and the amount of D-galactose remains intact. After centrifugation to remove the cells, the $\mathrm{pH}$ of supernatant is adjusted to 7.5 (because the medium is acidified during the treatment with P. pastoris) and $\mathrm{MnSO}_{4}$ is added to reach a final concentration of $0.5 \mathrm{mM}$. These adjustments prepare the mixture for the third step.

Finally, L-arabinose isomerase L-AI US100 is added $(0.65 \mathrm{U}$ per $\mathrm{mL}$ in the mixture, measured by the standard assay). The reaction is incubated at $65^{\circ} \mathrm{C}$ and different aliquots are taken to follow the progress of the reaction. As depicted in Figure 6, D-tagatose is formed and the final product contains a mixture of D-tagatose and D-galactose.

Figure 7 shows the progress of D-tagatose formation over time. The concentration of D-tagatose increases rapidly during the first four hours and then tends to stabilize in approximately $30 \mathrm{~g} / \mathrm{L}$. Starting of a whey permeate with $180 \mathrm{~g} / \mathrm{L}$ lactose, the yield of D-tagatose referred to lactose was 16.7\%, and $33.3 \%$ referred to the D-galactose present in whey. We believe that this yield could be improved by using a higher concentration of L-AI thus minimizing the enzyme inactivation effects (see Figure 3).

Wanarska et al. reported a 30\% yield of D-tagatose (referred to D-galactose) using a strain of Pichia pastoris that co-expressed L-AI and $\beta$-galactosidase, starting of a whey permeate containing $110 \mathrm{~g} / \mathrm{L}$ lactose [37]. Zheng et al. employed a whey with $110 \mathrm{~g} / \mathrm{L}$ lactose to get $43.6 \%$ yield of D-tagatose (referred to D-galactose) using a genetically engineered strain of Escherichia coli that expressed L-AI [32]. Similar results (40.4\% yield) were reported by Xu et al. employing E. coli that co-expressed a $\beta$-galactosidase from Thermus thermophilus and L-arabinose isomerase from Lactobacillus fermentum [38,39]. Jayamuthunagai et al. reported 38\% yield of D-tagatose (referred to D-galactose) from a hydrolyzed whey permeate containing $300 \mathrm{~g} / \mathrm{L}$ D-galactose, using permeabilized 
and alginate-entrapped cells of Lactobacillus plantarum [36]. Shen et al. expressed xylose isomerase and L-AI in a strain of Corynebacterium glutamicum able to metabolize lactose. Starting from whey containing $98 \mathrm{~g} / \mathrm{L}$ lactose, they obtained $20.4 \mathrm{~g} / \mathrm{L}$ D-tagatose (44\% yield referred to D-galactose) [33].

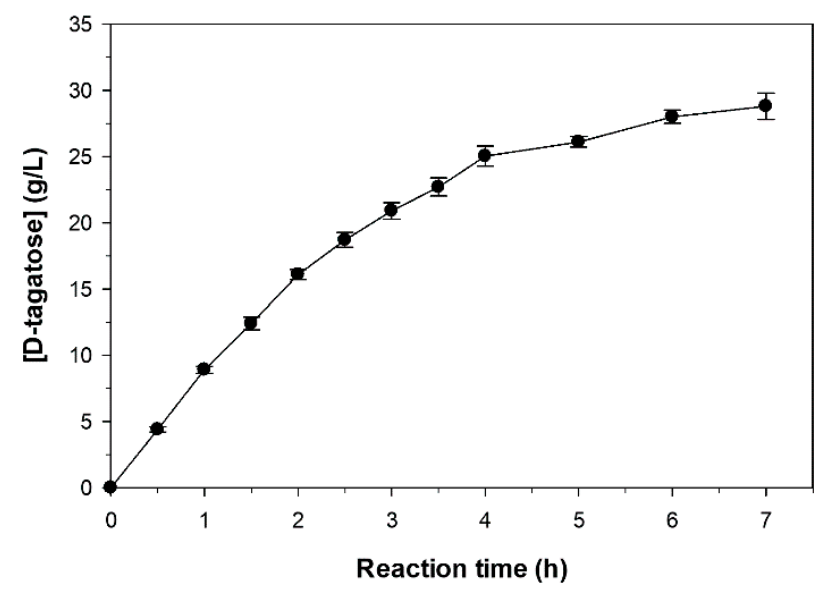

Figure 7. Progress of formation of D-tagatose from D-galactose syrup obtained by hydrolysis of whey permeate. Experimental conditions: $90 \mathrm{~g} / \mathrm{L} \mathrm{D}$-galactose (coming from $180 \mathrm{~g} / \mathrm{L}$ lactose in whey permeate), $0.65 \mathrm{U} / \mathrm{mL}$ L-arabinose isomerase US100, $0.5 \mathrm{mM} \mathrm{MnSO}_{4}, \mathrm{pH} 7.5,65{ }^{\circ} \mathrm{C}$.

A scheme summarizing the different steps of the integrated process is presented in Figure 8.

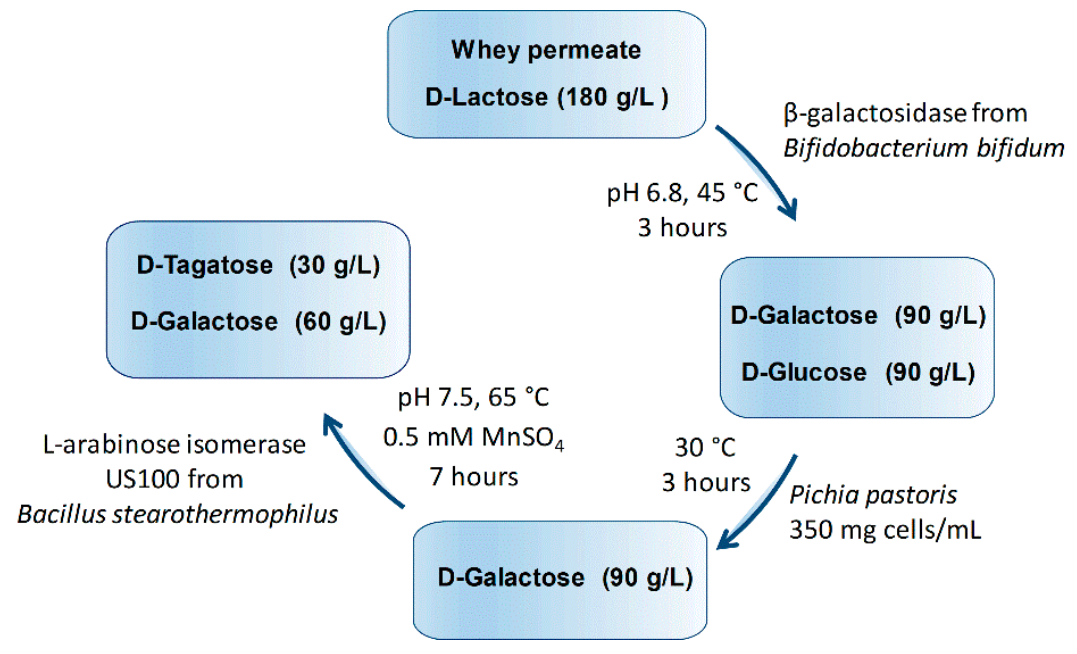

Figure 8. Scheme of the integrated process for bioconversion of whey permeate into D-tagatose syrup.

\section{Materials and Methods}

\subsection{Enzymes and Reagents}

L-Arabinose isomerase (L-AI) from Bacillus staerothermophilus US100 (L-AI US 100) was recombinantly produced in $E$. coli as described in previous publications $[50,52,53]$. The $\beta$-galactosidase from Bifidobacterium bifidus (Saphera ${ }^{\circledR}$, Novozym 46091) was gently donated by Novozymes A/S (Bagsværd, Denmark). Pichia pastoris GS115 (his4) was obtained from Invitrogen (Carlsbad, CA, USA). Concentrated whey permeate (180-200 g/L) was kindly donated by Innolact (Castro de Rei, Lugo, Spain). D-Galactose and D-glucose were purchased from Sigma-Aldrich (Madrid, Spain). D-Tagatose was acquired from Tokyo Chemical Industry Co. (Tokyo, Japan). Lactose and sodium acetate trihydrate were from Fisher Chemical (Madrid, Spain). $\mathrm{NaOH} \mathrm{50 \%} \mathrm{(v/v)} \mathrm{was} \mathrm{from} \mathrm{Acros} \mathrm{Organics} \mathrm{(Geel,} \mathrm{Belgium).}$ All other reagents and solvents were of the highest purity grade available. 


\subsection{Elemental Analysis of Whey Permeate using Inductive Coupled Plasma Mass Spectrometry}

Semiquantitative analysis of metals in whey permeate was performed on a NexION 300X Inductively Coupled Plasma-Mass Spectrometer (ICP-MS, PerkinElmer, Waltham, MA, USA) equipped with Universal Cell Technology, as previously described [54].

\section{3. $\beta$-Galactosidase Activity Assay}

The assay of $\beta$-galactosidase activity was performed using $o$-nitrophenyl- $\beta$-D-galactopyranoside (ONPG) as substrate. The activity was measured at $40{ }^{\circ} \mathrm{C}$ following $o$-nitrophenol (ONP) release at $405 \mathrm{~nm}$ using a microplate reader (Versamax, Molecular Devices, San Jose, CA, USA). The reaction was started by adding $10 \mu \mathrm{L}$ of the enzyme solution (properly diluted) to $190 \mu \mathrm{L}$ of $15 \mathrm{mM}$ ONPG in $0.1 \mathrm{M}$ sodium phosphate buffer ( $\mathrm{pH}$ 6.8). The increase of absorbance at $405 \mathrm{~nm}$ was followed continuously at $40{ }^{\circ} \mathrm{C}$ during $5 \mathrm{~min}$. The molar extinction coefficient of $o$-nitrophenol at $\mathrm{pH} 6.8$ was $1627 \mathrm{M}^{-1} \mathrm{~cm}^{-1}$. One unit of activity $(U)$ was defined as the corresponding to the hydrolysis of $1 \mu \mathrm{mol}$ of ONPG per min under the above specified conditions.

\subsection{Lactose Hydrolysis in Whey by Bifidobacterium Bifidum $\beta$-Galactosidase}

Concentrated whey permeate ( $2 \mathrm{~mL}$, containing 180-200 g/L lactose) was mixed with $\beta$-galactosidase from Bifidobacterium bifidum (Saphera ${ }^{\circledR}, 5-10 \mu \mathrm{L}, 3.75-7.5$ ONPG units per $\mathrm{mL}$ ). The mixture was incubated at 30,40 or $45^{\circ} \mathrm{C}$ in an orbital shaker (Vortemp 1550, Labnet International, Big Flats, NY, USA) at $200 \mathrm{rpm} .200 \mu \mathrm{L}$ aliquots were taken from the reaction vial each 30 minutes until 3 hours. The enzyme was then inactivated by incubating the samples in a Thermomixer (Eppendorf, Hamburg, Germany) for $10 \mathrm{~min}$ at $95^{\circ} \mathrm{C}$. Samples were then filtered using micro-centrifuge filter tubes, with $0.45 \mu \mathrm{m}$ cellulose acetate filters (National Scientific, Claremont, CA, USA) at $6000 \mathrm{rpm}$ for $5 \mathrm{~min}$. The samples were diluted with water (1:400 and 1:4000) and then analysed using HPAEC-PAD.

\subsection{Effect of Growth Time and Concentration of Pichia pastoris on the Elimination of D-Glucose}

Pichia pastoris preculture was grown in $5 \mathrm{~mL}$ of $1 \%$ yeast extract, $1 \%$ peptone and $2 \%$ dextrose (all $w / v$ ) liquid medium (YEPD) at $30^{\circ} \mathrm{C}$ and $1200 \mathrm{rpm}$ for $24 \mathrm{~h}$. After this time, the absorbance was measured, and $1 \mathrm{~mL}$ of preculture was added to a $250 \mathrm{~mL}$ flask containing $25 \mathrm{~mL}$ of YEPD, which was left growing at $30^{\circ} \mathrm{C}$ and $1200 \mathrm{rpm}$. The first sample was taken at $6 \mathrm{~h}$. The optical density (OD) was measured at $600 \mathrm{~nm}$ in a UV-1800 spectrophotometer (Shimadzu, Kioto, Japan) taking this OD as the reference value. The cells were centrifuged and washed three times with distilled water to remove the remaining medium from the cells. Samples were taken every $2 \mathrm{~h}$ until $24 \mathrm{~h}$. Before centrifugation, all the samples were diluted to reach the reference value of absorbance, with the aim of having the same amount of cells in the experiments but with different growing times. Reactions with P. pastoris cells were performed adding $500 \mu \mathrm{L}$ of a solution containing $1 \mathrm{~g} / \mathrm{L} \mathrm{D}$-glucose and $1 \mathrm{~g} / \mathrm{L}$ D-galactose to the cells. Reactions were incubated in a tube rotator (Argos Technologies Inc., Vernon Hills, IL, USA) for $10 \mathrm{~min}$ at $30^{\circ} \mathrm{C}$, then samples were centrifuged, the supernatant was inactivated at $95^{\circ} \mathrm{C}$ for $10 \mathrm{~min}$ and analyzed by HPAEC-PAD. To determine the amount of cells required to consume the glucose expected in the sequential process for production of D-tagatose, different amounts of P. pastoris cells $(300,400$, 500 and $600 \mathrm{mg}$ of wet weight) were added to $1 \mathrm{~mL}$ of a solution containing $100 \mathrm{~g} / \mathrm{L} \mathrm{D}$-glucose and $100 \mathrm{~g} / \mathrm{L}$ D-galactose. Aliquots were withdrawn at 1, 2 and $3 \mathrm{~h}$. After each extraction, the samples were centrifuged at 10,000 rpm for $3 \mathrm{~min}$ and the concentration of glucose and galactose in the supernatant was analyzed by HPAEC-PAD.

\subsection{L-Arabinose Isomerase Activity Assay}

The L-arabinose isomerase (L-AI) activity was determined adding the enzyme to a solution containing $20 \mathrm{~g} / \mathrm{L}$ of D-galactose in $100 \mathrm{mM}$ MOPS buffer (pH 7.5) containing $0.5 \mathrm{mM} \mathrm{MnSO}_{4}$ and $0.1 \mathrm{mM} \mathrm{CoCl}_{2}$. The mixture was incubated at $65{ }^{\circ} \mathrm{C}$ for $4 \mathrm{~h}$, and the reaction stopped in a water bath at 
$90{ }^{\circ} \mathrm{C}$ for $10 \mathrm{~min}$. The concentration of D-tagatose was measured by HPAEC-PAD. One unit of L-AI activity (U) was defined as the corresponding to the formation of $1 \mu \mathrm{mol}$ of D-tagatose per minute, under the conditions specified above.

\subsection{Stability of L-Arabinose Isomerase}

The stability of L-arabinose isomerase (L-AI US 100) from B. stearothermophilus towards $\mathrm{pH}$ was assessed pre-incubating the enzyme at different $\mathrm{pH}$ values (3.0 to 10.0) in $0.1 \mathrm{M}$ Britton \& Robinson buffer [55] at room temperature for $1 \mathrm{~h}$. The thermal stability of the enzyme was determined by pre-incubating the L-AI at 4, 20, 30, 40, 50, 65, 70 and $80^{\circ} \mathrm{C}$ in $100 \mathrm{mM}$ MOPS buffer (pH 7.5) for $1 \mathrm{~h}$. After incubation, the remaining L-arabinose isomerase activity was measured following the standard activity assay (Section 3.6). The activity of pre-treated L-AI US100 was compared with the activity of non-pre-incubated enzyme that was taken as control $(100 \%)$.

\subsection{Effect of Metals, $\mathrm{pH}$ and Temperature on the Activity of L-Arabinose Isomerase}

To analyze the effect of metal cofactors on the activity of L-arabinose isomerase (L-AI US 100), different reactions were carried out in presence of $0.5 \mathrm{mM} \mathrm{MnSO}_{4}$ and/or $0.1 \mathrm{mM} \mathrm{CoCl}_{2}$. The reactions were carried out with $20 \mathrm{~g} / \mathrm{L}$ galactose in $100 \mathrm{mM}$ MOPS buffer (pH 7.5) at $65^{\circ} \mathrm{C}$ for $4 \mathrm{~h}$, using $0.65 \mathrm{U} / \mathrm{mL}$ $\mathrm{L}-\mathrm{AI}$, and the concentration of D-tagatose was determined by HPAEC-PAD. A control reaction without cofactors was also performed. To determine the best reaction conditions for the enzyme, different values of $\mathrm{pH}(7,7.5,8,8.5,9,9.5)$ and temperature $\left(40,50,60\right.$ and $\left.65^{\circ} \mathrm{C}\right)$ were tested, in a reaction containing $20 \mathrm{~g} / \mathrm{L}$ of D-galactose, $0.5 \mathrm{mM}$ of $\mathrm{MnSO}_{4}$ in $100 \mathrm{mM}$ MOPS buffer (pH 7.5) and $0.65 \mathrm{U} / \mathrm{mL}$ L-AI. After $4 \mathrm{~h}$, the reaction mixtures were analyzed by HPAEC-PAD.

\subsection{Sequential Biotransformation of Whey Permeate into D-Tagatose}

The biosynthesis of D-tagatose syrup from whey permeate was performed in three steps. Initially, the $\mathrm{pH}$ of whey was adjusted to 6.8. In the first stage, $\beta$-galactosidase from Bifidobacterium bifidum $(5 \mu \mathrm{L}, 7.5 \mathrm{U} / \mathrm{mL}$ measured with ONPG) was added to $2 \mathrm{~mL}$ of concentrated whey permeate (containing 180-200 g/L lactose, depending on the batch). The mixture was incubated for $3 \mathrm{~h}$ in an Envirogenie orbital stirrer (Scientific Industries Inc., Bohemia, NY, USA) at $45^{\circ} \mathrm{C}$. The second step involved the treatment of the hydrolyzate with $700 \mathrm{mg}$ (wet weight) of Pichia pastoris cells (previously grown for $16 \mathrm{~h}$ ) and the mixture was incubated in an orbital shaker (Orbitron, Infors HT, Surrey, UK) for $3 \mathrm{~h}$ at $30{ }^{\circ} \mathrm{C}$. Then, the cells were removed by centrifugation (model 5810, Eppendorf) at $5000 \mathrm{rpm}$ for $20 \mathrm{~min}$ at $4{ }^{\circ} \mathrm{C}$. The supernatant was then separated from the cells and inactivated in a water bath at $90^{\circ} \mathrm{C}$ for $10 \mathrm{~min}$. In the third stage, the $\mathrm{pH}$ of supernatant was adjusted to 7.5 and $\mathrm{MnSO}_{4}$ was added up to a final concentration of $0.5 \mathrm{mM}$. Then, 1.3 units of L-arabinose isomerase L-AI US100 were added $(0.65 \mathrm{U} / \mathrm{mL}$ in the mixture). The reaction was incubated in a thermoshaker (model TS-100, Biosan, Riga, Latvia) at $65{ }^{\circ} \mathrm{C}$ and $1500 \mathrm{rpm}$. Aliquots were taken every $30 \mathrm{~min}$, filtered on UltraFree centrifugal filters ( $0.45 \mu \mathrm{m}$, Millipore, Burlington, MA, USA) and analysed by HPAEC-PAD.

\subsection{HPAEC-PAD Analysis}

Sugar (D-galactose, D-glucose, D-tagatose, D-fructose and D-lactose) analysis was carried out by high performance anion-exchange chromatography coupled with pulsed amperometric detection (HPAEC-PAD) on an ICS3000 system (Dionex, Thermo Fischer Scientific Inc., Waltham, MA, USA) consisting of a SP gradient pump, an electrochemical detector with a gold working electrode and $\mathrm{Ag} / \mathrm{AgCl}$ as reference electrode, and an autosampler (model AS-HV). All eluents were degassed by flushing with helium. A pellicular anion-exchange $4 \times 250 \mathrm{~mm}$ Carbo-Pack PA-1 column (Dionex) connected to a $4 \times 50 \mathrm{~mm}$ CarboPac PA-1 guard column was used at $30^{\circ} \mathrm{C}$. Eluent preparation was performed with MilliQ water, $50 \%(w / v) \mathrm{NaOH}$ and sodium acetate trihydrate. The compounds were eluted by an isocratic method in which the mobile phase contained $10 \mathrm{mM} \mathrm{NaOH}$ and $2 \mathrm{mM}$ sodium acetate, using a flow rate of $1 \mathrm{~mL} / \mathrm{min}$ for $25 \mathrm{~min}$. The peaks were analyzed using the Chromeleon 
software. Identification of the different carbohydrates was carried out employing commercially available standards.

\section{Conclusions}

The present work describes an environmentally friendly process for the bioconversion of cheese whey, a lactose-rich byproduct of the food industry, into D-tagatose, a rare sugar that has become one of the most promising low-calorie sweeteners in the market due to its functional properties. The methodology is based in the complete hydrolysis of lactose by a bifidobacterial $\beta$-galactosidase, followed by the selective removal of glucose with Pichia pastoris cells, and finally the isomerization of the remaining D-galactose into D-tagatose by L-arabinose isomerase from Bacillus stearothermophilus. The three steps were optimized independently in such a way that the integrated process is carried out in a short time ( $13 \mathrm{~h}$ ) yielding $33.3 \%$ of D-tagatose (referred to the initial D-galactose). The total time could be even reduced by using a higher concentration of L-AI in the third step. One of the main advantages of the proposed project is its sustainability, as the three steps take place under mild conditions of $\mathrm{pH}(6.8-7.5)$, moderate temperatures $\left(30-65^{\circ} \mathrm{C}\right)$ and with completely biodegradable catalysts. The final syrup is free of glucose, and contains D-tagatose and D-galactose in a ratio 1:2 (w/w). This work opens new possibilities for the synthesis of D-tagatose and for the development of different reaction engineering strategies including enzyme immobilization.

Author Contributions: F.J.P., S.B. and A.O.B. conceived and designed the experiments; F.V.C. carried out most of the experiments; S.N. and S.B. produced and characterized the L-AI US100; Z.M., J.V.-G. and M.F.-L. were in charge of the microbiological issues in this work; L.F.-A. contributed to the chromatographic analysis of carbohydrates; F.J.P. wrote the paper, which was improved by the rest of authors. All authors have read and agreed to the published version of the manuscript.

Funding: This work was supported by grants from the Spanish Ministry of Economy and Competitiveness (Grants BIO2016-76601-C3-1-R and C3-2-R) and Fundación Ramón Areces (XIX Call of Research Grants in Life and Material Sciences). We thank Fundación Ramón Areces for an institutional grant to the Center of Molecular Biology Severo Ochoa. F.V. Cervantes thanks CONACYT (Mexico) for her Ph.D. fellowship (Ref. 440242).

Acknowledgments: We thank Ramiro Martinez (Novozymes A/S, Spain) for supplying Saphera and for useful suggestions. We are grateful to Innolact (Castro de rei, Lugo, Spain) for donating concentrated whey permeate. We acknowledge support of the publication fee by the CSIC Open Access Publication Support Initiative through its Unit of Information Resources for Research (URICI).

Conflicts of Interest: The authors declare no conflict of interest.

\section{References}

1. Torrico, D.D.; Tam, J.; Fuentes, S.; Viejo, C.G.; Dunshea, F.R. D-tagatose as a sucrose substitute and its effect on the physico-chemical properties and acceptability of strawberry-flavored yogurt. Foods 2019, 8, 256. [CrossRef] [PubMed]

2. Oh, D.K. Tagatose: Properties, applications, and biotechnological processes. Appl. Microbiol. Biotechnol. 2007, 76, 1-8. [CrossRef] [PubMed]

3. Von Rymon Lipinski, G.-W. Sweeteners. In Biotechnology of Food and Feed Additives; Zorn, H., Czermak, P., Eds.; Springer: Berlin, Germany, 2014; pp. 1-28. [CrossRef]

4. Acevedo, W.; Capitaine, C.; Rodríguez, R.; Araya-Durán, I.; González-Nilo, F.; Pérez-Correa, J.R.; Agosin, E. Selecting optimal mixtures of natural sweeteners for carbonated soft drinks through multi-objective decision modeling and sensory validation. J. Sens. Stud. 2018, 33, 6. [CrossRef]

5. Levin, G.V. Tagatose, the new GRAS sweetener and health product. J. Med. Food 2002, 5, 23-36. [CrossRef] [PubMed]

6. Roy, S.; Chikkerur, J.; Roy, S.C.; Dhali, A.; Kolte, A.P.; Sridhar, M.; Samanta, A.K. Tagatose as a potential nutraceutical: Production, properties, biological roles, and applications. J. Food Sci. 2018, 83, 2699-2709. [CrossRef] [PubMed]

7. Rubio-Arraez, S.; Ferrer, C.; Capella, J.V.; Ortolá, M.D.; Castelló, M.L. Development of lemon marmalade formulated with new sweeteners (isomaltulose and tagatose): Effect on antioxidant, rheological and optical properties. J. Food Process Eng. 2017, 40, e12371. [CrossRef] 
8. Manzo, R.M.; Antunes, A.S.L.M.; de Sousa Mendes, J.; Hissa, D.C.; Gonçalves, L.R.B.; Mammarella, E.J. Biochemical characterization of heat-tolerant recombinant L-arabinose isomerase from Enterococcus faecium DBFIQ E36 strain with feasible applications in D-tagatose production. Mol. Biotechnol. 2019, 61, 385-399. [CrossRef] [PubMed]

9. $\quad$ Liang, Y.X.; Wen, P.; Wang, Y.; Ouyang, D.M.; Wang, D.; Chen, Y.Z.; Song, Y.; Deng, J.; Sun, Y.M.; Wang, H. The constipation-relieving property of D-tagatose by modulating the composition of gut microbiota. Int. J. Mol. Sci. 2019, 20, 5721. [CrossRef] [PubMed]

10. Espinosa, I.; Fogelfeld, L. Tagatose: From a sweetener to a new diabetic medication? Expert Opin. Investig. Drugs 2010, 19, 285-294. [CrossRef] [PubMed]

11. Lu, Y.; Levin, G.V.; Donner, T.W. Tagatose, a new antidiabetic and obesity control drug. Diabetes Obes. Metab. 2008, 10, 109-134. [CrossRef] [PubMed]

12. Nagata, Y.; Mizuta, N.; Kanasaki, A.; Tanaka, K. Rare sugars, D-allulose, D-tagatose and D-sorbose, differently modulate lipid metabolism in rats. J. Sci. Food Agric. 2018, 98, 2020-2026. [CrossRef] [PubMed]

13. Cheng, S.; Metzger, L.E.; Martínez-Monteagudo, S.I. One-pot synthesis of sweetening syrup from lactose. Sci. Rep. 2020, 10, 1-9. [CrossRef] [PubMed]

14. Drabo, P.; Delidovich, I. Catalytic isomerization of galactose into tagatose in the presence of bases and Lewis acids. Catal. Commun. 2018, 107, 24-28. [CrossRef]

15. Freimund, S.; Huwig, A.; Giffhorn, F.; Köpper, S. Convenient chemo-enzymatic synthesis of D-tagatose. J. Carbohydr. Chem. 1996, 15, 115-120. [CrossRef]

16. Sha, F.; Zheng, Y.; Chen, J.; Chen, K.; Cao, F.; Yan, M.; Ouyang, P. D-Tagatose manufacture through bio-oxidation of galactitol derived from waste xylose mother liquor. Green Chem. 2018, 20, 2382-2391. [CrossRef]

17. Bober, J.R.; Nair, N.U. Galactose to tagatose isomerization at moderate temperatures with high conversion and productivity. Nat. Commun. 2019, 10, 4548. [CrossRef] [PubMed]

18. Patel, M.J.; Patel, A.T.; Akhani, R.; Dedania, S.; Patel, D.H. Bioproduction of D-tagatose from D-galactose using phosphoglucose isomerase from Pseudomonas aeruginosa PAO1. Appl. Biochem. Biotechnol. 2016, 179, 715-727. [CrossRef] [PubMed]

19. Jagtap, S.S.; Singh, R.; Kang, Y.C.; Zhao, H.; Lee, J.K. Cloning and characterization of a galactitol 2-dehydrogenase from Rhizobium legumenosarum and its application in D-tagatose production. Enzyme Microb. Technol. 2014, 58-59, 44-51. [CrossRef] [PubMed]

20. Boudebbouze, S.; Maguin, E.; Rhimi, M. Bacterial L-arabinose isomerases: Industrial application for D-tagatose production. Recent Pat. DNA Gene Seq. 2011, 5, 194-201. [CrossRef] [PubMed]

21. Chouayekh, H.; Bejar, W.; Rhimi, M.; Jelleli, K.; Mseddi, M.; Bejar, S. Characterization of an L-arabinose isomerase from the Lactobacillus plantarum NC8 strain showing pronounced stability at acidic $\mathrm{pH}$. FEMS Microbiol. Lett. 2007, 277, 260-267. [CrossRef] [PubMed]

22. De Sousa, M.; Melo, V.M.M.; Hissa, D.C.; Manzo, R.M.; Mammarella, E.J.; Antunes, A.S.L.M.; García, J.L.; Pessela, B.C.; Gonçalves, L.R.B. One-step immobilization and stabilization of a recombinant Enterococcus faecium DBFIQ E36 L-arabinose isomerase for D-tagatose synthesis. Appl. Biochem. Biotechnol. 2019, 188, 310-325. [CrossRef] [PubMed]

23. Du, M.; Zhao, D.; Cheng, S.; Sun, D.; Chen, M.; Gao, Z.; Zhang, C. Towards efficient enzymatic conversion of D-galactose to D-tagatose: Purification and characterization of L-arabinose isomerase from Lactobacillus brevis. Bioprocess Biosyst. Eng. 2019, 42, 107-116. [CrossRef] [PubMed]

24. Mei, W.; Wang, L.; Zang, Y.; Zheng, Z.; Ouyang, J. Characterization of an L-arabinose isomerase from Bacillus coagulans NL01 and its application for D-tagatose production. BMC Biotechnol. 2016, 16, 55. [CrossRef] [PubMed]

25. Nguyen, T.K.; Hong, M.G.; Chang, P.S.; Lee, B.H.; Yoo, S.H. Biochemical properties of L-arabinose isomerase from Clostridium hylemonae to produce D-tagatose as a functional sweetener. PLoS ONE 2018, 13, e0196099. [CrossRef] [PubMed]

26. Zheng, Z.; Mei, W.; Xia, M.; He, Q.; Ouyang, J. Rational DESIGN of Bacillus coagulans NL01 L-arabinose isomerase and use of its F279I variant in D-tagatose production. J. Agric. Food Chem. 2017, 65, 4715-4721. [CrossRef] [PubMed]

27. Liu, Y.; Li, S.; Xu, H.; Wu, L.; Xu, Z.; Liu, J.; Feng, X. Efficient production of D-tagatose using a food-grade surface display system. J. Agric. Food Chem. 2014, 62, 6756-6762. [CrossRef] [PubMed] 
28. Guo, Q.; An, Y.; Yun, J.; Yang, M.; Magocha, T.A.; Zhu, J.; Xue, Y.; Qi, Y.; Hossain, Z.; Sun, W.; et al. Enhanced D-tagatose production by spore surface-displayed L-arabinose isomerase from isolated Lactobacillus brevis PC16 and biotransformation. Bioresour. Technol. 2018, 247, 940-946. [CrossRef] [PubMed]

29. Jeong, D.W.; Hyeon, J.E.; Shin, S.K.; Han, S.O. Trienzymatic complex system for isomerization of agar-derived D-galactose into D-tagatose as a low-calorie sweetener. J. Agric. Food Chem. 2020, 68, 3195-3202. [CrossRef] [PubMed]

30. Zhang, G.; Zabed, H.M.; Yun, J.; Yuan, J.; Zhang, Y.; Wang, Y.; Qi, X. Two-stage biosynthesis of D-tagatose from milk whey powder by an engineered Escherichia coli strain expressing L-arabinose isomerase from Lactobacillus plantarum. Bioresour. Technol. 2020, 305, 123010. [CrossRef] [PubMed]

31. Illanés, A. Whey upgrading by enzyme biocatalysis. Electron. J. Biotechnol. 2011, 14, 9. [CrossRef]

32. Zheng, Z.; Xie, J.; Liu, P.; Li, X.; Ouyang, J. Elegant and efficient biotransformation for dual production of D-tagatose and bioethanol from cheese whey powder. J. Agric. Food Chem. 2019, 67, 829-835. [CrossRef] [PubMed]

33. Shen, J.; Chen, J.; Jensen, P.R.; Solem, C. Sweet as sugar-Efficient conversion of lactose into sweet sugars using a novel whole-cell catalyst. J. Agric. Food Chem. 2019, 67, 6257-6262. [CrossRef] [PubMed]

34. Torres, P.; Batista-Viera, F. Production of D-tagatose and D-fructose from whey by co-immobilized enzymatic system. Mol. Catal. 2019, 463, 99-109. [CrossRef]

35. Nath, A.; Verasztó, B.; Basak, S.; Koris, A.; Kovács, Z.; Vatai, G. Synthesis of lactose-derived nutraceuticals from dairy waste whey-A review. Food Bioprocess Technol. 2016, 9, 16-48. [CrossRef]

36. Jayamuthunagai, J.; Srisowmeya, G.; Chakravarthy, M.; Gautam, P. D-Tagatose production by permeabilized and immobilized Lactobacillus plantarum using whey permeate. Bioresour. Technol. 2017, 235, 250-255. [CrossRef] [PubMed]

37. Wanarska, M.; Kur, J. A method for the production of D-tagatose using a recombinant Pichia pastoris strain secreting $\beta$-D-galactosidase from Arthrobacter chlorophenolicus and a recombinant L-arabinose isomerase from Arthrobacter sp. 22c. Microb. Cell Fact. 2012, 11, 113. [CrossRef] [PubMed]

38. Xu, Z.; Xu, Z.; Tang, B.; Li, S.; Gao, J.; Chi, B.; Xu, H. Construction and co-expression of polycistronic plasmids encoding thermophilic L-arabinose isomerase and hyperthermophilic $\beta$-galactosidase for single-step production of D-tagatose. Biochem. Eng. J. 2016, 109, 28-34. [CrossRef]

39. Zhan, Y.; Xu, Z.; Li, S.; Liu, X.; Xu, L.; Feng, X.; Xu, H. Coexpression of $\beta$-D-galactosidase and L-arabinose isomerase in the production of D-tagatose: A functional sweetener. J. Agric. Food Chem. 2014, 62, 2412-2417. [CrossRef] [PubMed]

40. Plou, F.J.; Polaina, J.; Sanz-Aparicio, J.; Fernandez-Lobato, M. $\beta$-Galactosidases for lactose hydrolysis and galactooligosaccharide synthesis. In Microbial Enzyme Technology in Food Applications; Ray, R.C., Rosell, C.M., Eds.; CRC Press: Boca Raton, FL, USA, 2016; pp. 123-146.

41. Jørgensen, F.; Hansen, O.C.; Stougaard, P. Enzymatic conversion of D-galactose to D-tagatose: Heterologous expression and characterisation of a thermostable L-arabinose isomerase from Thermoanaerobacter mathranii. Appl. Microbiol. Biotechnol. 2004, 64, 816-822. [CrossRef] [PubMed]

42. Santibáñez, L.; Fernández-Arrojo, L.; Guerrero, C.; Plou, F.J.; Illanes, A. Removal of lactose in crude galacto-oligosaccharides by $\beta$-galactosidase from Kluyveromyces lactis. J. Mol. Catal. B Enzym. 2016, 133, 85-91. [CrossRef]

43. Füreder, V.; Rodriguez-Colinas, B.; Cervantes, F.; Fernandez-Arrojo, L.; Poveda, A.; Jimenez-Barbero, J.; Ballesteros, A.O.; Plou, F.J. Selective synthesis of galactooligosaccharides containing $\beta(1 \rightarrow 3)$ linkages with $\beta$-galactosidase from Bifidobacterium bifidum (Saphera). J. Agric. Food Chem. 2020, 68, 4930-4938. [CrossRef] [PubMed]

44. Hsu, C.A.; Lee, S.L.; Chou, C.C. Enzymatic production of galactooligosaccharides by beta-galactosidase from Bifidobacterium longum BCRC 15708. J. Agric. Food Chem. 2007, 55, 2225-2230. [CrossRef] [PubMed]

45. Goulas, A.; Tzortzis, G.; Gibson, G.R. Development of a process for the production and purification of alphaand beta-galactooligosaccharides from Bifobacterium bifidum NCIMB 41171. Int. Dairy J. 2007, 17, 648-656. [CrossRef]

46. Mattanovich, D.; Graf, A.; Stadlmann, J.; Dragosits, M.; Redl, A.; Maurer, M.; Kleinheinz, M.; Sauer, M.; Altmann, F.; Gasser, B. Genome, secretome and glucose transport highlight unique features of the protein production host Pichia pastoris. Microb. Cell Fact. 2009, 8, 29. [CrossRef] [PubMed] 
47. Ávila-Fernández, Á.; Galicia-Lagunas, N.; Rodríguez-Alegría, M.E.; Olvera, C.; López-Munguía, A. Production of functional oligosaccharides through limited acid hydrolysis of agave fructans. Food Chem. 2011, 129, 380-386. [CrossRef] [PubMed]

48. Potvin, G.; Zhang, Z.; Defela, A.; Lam, H. Screening of alternative carbon sources for recombinant protein production in Pichia pastoris. Int. J. Chem. React. Eng. 2016, 14, 251-257. [CrossRef]

49. Rhimi, M.; Bejar, S. Cloning, purification and biochemical characterization of metallic-ions independent and thermoactive L-arabinose isomerase from the Bacillus stearothermophilus US100 strain. Biochim. Biophys. Acta Gen. Subj. 2006, 1760, 191-199. [CrossRef] [PubMed]

50. Rhimi, M.; Aghajari, N.; Juy, M.; Chouayekh, H.; Maguin, E.; Haser, R.; Bejar, S. Rational design of Bacillus stearothermophilus US100 L-arabinose isomerase: Potential applications for D-tagatose production. Biochimie 2009, 91, 650-653. [CrossRef] [PubMed]

51. Lee, S.-J.; Lee, D.-W.; Choe, E.-A.; Hong, Y.-H.; Kim, S.-B.; Kim, B.-C.; Pyun, Y.-R. Characterization of a Characterization of a thermoacidophilic L-arabinose isomerase from Alicyclobacillus acidocaldarius: Role of Lys-269 in pH optimum. Appl. Environ. Microbiol. 2005, 71, 7888. [CrossRef] [PubMed]

52. Rhimi, M.; Juy, M.; Aghajari, N.; Haser, R.; Bejar, S. Probing the essential catalytic residues and substrate affinity in the thermoactive Bacillus stearothermophilus US100 L-arabinose isomerase by site-directed mutagenesis. J. Bacteriol. 2007, 189, 3556-3563. [CrossRef] [PubMed]

53. Rhimi, M.; Messaoud, E.B.; Borgi, M.A.; khadra, K.B.; Bejar, S. Co-expression of L-arabinose isomerase and D-glucose isomerase in E. coli and development of an efficient process producing simultaneously D-tagatose and D-fructose. Enzyme Microb. Technol. 2007, 40, 1531-1537. [CrossRef]

54. Zuluaga, J.; Rodríguez, N.; Rivas-Ramirez, I.; De La Fuente, V.; Rufo, L.; Amils, R. An improved semiquantitative method for elemental analysis of plants using inductive coupled plasma mass spectrometry. Biol. Trace Elem. Res. 2011, 144, 1302-1317. [CrossRef] [PubMed]

55. Britton, H.T.S.; Robinson, R.A. Universal buffer solutions and the dissociation constant of veronal. J. Chem. Soc. 1931, 1456-1462. [CrossRef]

(C) 2020 by the authors. Licensee MDPI, Basel, Switzerland. This article is an open access article distributed under the terms and conditions of the Creative Commons Attribution (CC BY) license (http://creativecommons.org/licenses/by/4.0/). 